\title{
Recenzja
}

\section{Edyta Tkaczyk, Realizacja prawa inicjatywy ustawodawczej w polskim prawie konstytucyjnym, Wydawnictwo Sejmowe, Warszawa 2014, ss. 291}

Realizacja prawa inicjatywy ustawodawczej uruchamia proces, który prowadzi do uchwalenia ustawy, aktu umiejscowionego w hierarchii źródeł prawa bezpośrednio po konstytucji. Pomimo istotnej, inicjującej proces dochodzenia ustawy do skutku, roli inicjatywy ustawodawczej w literaturze nie poświęcano dotychczas temu zagadnieniu zbyt dużo systematycznej uwagi. Próbę w miarę kompleksowego przeanalizowania tej problematyki, podjęła Edyta Tkaczyk. Autorka już na wstępie recenzowanej książki zaznacza, że jest świadoma złożoności i wieloaspektowości problematyki z którą zdecydowała się zmierzyć. Podkreśla też, że zagadnienie inicjatywy ustawodawczej może być rozważane $\mathrm{z}$ różnych perspektyw badawczych, ponieważ ma związek z szeregiem różnorodnych problemów. Ze swej strony za szczególnie cenny uważam jeden $\mathrm{z}$ wątków wielokrotnie poruszany $\mathrm{w}$ pracy, mianowicie próbę udzielenia odpowiedzi na pytanie - czy obowiązujące obecnie procedury przygotowywania projektu ustawy są wystarczające dla stworzenia efektywnie poprawnego legislacyjnie i merytorycznie projektu?

W części I monografii zatytułowanej Prawo inicjatywy ustawodawczej Autorka podjęła próbę zdefiniowania zawartego w tytule rozdziału pojęcia. Trafnie oddziela pojęcie inicjatywy ustawodawczej od prawa inicjatywy ustawodawczej, wskazując na istnienie wyraźnych różnic pomiędzy tymi dwoma terminami. Następnie w miarę kompleksowo analizuje pojęcie „in- 
spiracji ustawodawczej” poprzez scharakteryzowanie podmiotów, które zostały w ten przywilej wyposażone.

Kontynuując rozważania dotyczące siatki pojęciowej związanej z prawem inicjatywy ustawodawczej, Autorka nawiązała do krytycznych opinii o stanowionym współcześnie w Polsce prawie, dokonując próby udzielenia odpowiedzi na zadane we wstępie pytanie. Swoje rozważania podsumowuje istotnym stwierdzeniem: „dobre prawo będzie wówczas, gdy procedury legislacyjne będą tak skonstruowane, żeby służyć opracowywaniu dobrego prawa" (s. 22). Dokonując analizy poglądów przedstawicieli doktryny, wśród których wciąż istnieje mało dziś przekonująca idea stworzenia aktu, który zawierałby kompleksowe uregulowania dotyczące procesu tworzenia prawa, stwierdza, że żadne przepisy nie wymuszą na żadnym z uprawnionych podmiotów obowiązku przedstawiania Sejmowi tylko projektów „wysokiej jakości”. Obecnie bowiem potrzeba czegoś innego niż prawa - wysokiej kultury politycznej (sic!).

Atrybutem monografii E. Tkaczyk jest jej praktyczny wymiar. Autorka dokonuje bowiem kompleksowej analizy czynników, które należy uwzględnić podczas przygotowywania projektu ustawy.

W monografii nie zabrakło także nawiązania do historii kształtowania się w RP prawa inicjatywy ustawodawczej. Istotnym jest także to, że kontekst historyczny uwzględniony przez Autorkę nie wykracza poza minimum niezbędne dla kompleksowego scharakteryzowania analizowanej instytucji. Edyta Tkaczyk przybliża uregulowania dotyczące prawa inicjatywy ustawodawczej zawarte w Konstytucji z 1997 r., omawiając jednocześnie projekty konstytucji wniesione w 1993 r. do Komisji Konstytucyjnej Zgromadzenia Narodowego. Zaznacza, że kształtowanie obecnej postaci prawa inicjatywy ustawodawczej przebiegało w oparciu o kilka propozycji przedstawianych przez różne ugrupowania polityczne. Problematyka ta bowiem w projektach stanowiących podstawę prac konstytucyjnych była ujęta szeroko i szczęśliwie zbieżnie. Wszystkie projekty nowej konstytucji złożone w 1993 r. zakładały jednak zgodnie, że suwerenem powinien być ogół obywateli.

W rozdziale II monografii Autorka analizuje charakter prawny Regulaminu Sejmu (Senatu), zwracając uwagę na jego szczególny, ścisły związek z konstytucją. Bada zagadnienie zasięgu podmiotowego i przedmiotowego regulaminów oraz wskazuje, jakie konsekwencje z przyjętych w tym akcie normatywnym uregulowań wynikają dla podmiotów przygotowujących projekt ustawy. 
Podobnie jak w pierwszym rozdziale, można i tu dostrzec oraz docenić praktyczny walor monografii. Za wartościowe uważam rozważania dotyczące „preinicjatywy”. Autorka zaznacza, że przed przystąpieniem do przygotowywania projektu ustawy należy wymienić podstawowe cele, które następnie należy realizować. Następnie dokonuje enumeratywnego ich wymienienia, zaznaczając m.in. konieczność przeprowadzenia badań prelegislacyjnych w celu udzielenia odpowiedzi na pytanie, czy uchwalenie danej ustawy jest w ogóle konieczne. Jest to diagnoza i oczekiwanie zarazem bardzo trudne, zwłaszcza że izby parlamentu polskiego od dawna cierpią na przerost swoistej „manii ustawodawczej”. Tkaczyk podkreśla, że tylko dobrze przygotowany projekt ustawy stanowi gwarancję dobrego prawa, w związku z tym podmioty zajmujące się jego opracowaniem powinny kierować się w swoich działaniach przeświadczeniem, że tworzą projekt przyszłej ustawy, która następnie stanie się częścią rodzimego systemu prawnego.

Autorka krytycznie odnosi się do braku analogicznych zasad modelu postępowania z przygotowywaniem projektu ustawy. Trafnie zauważa niesymetryczność, brak równych możliwości przeprowadzenia szczegółowych badań mających za zadanie potwierdzenie celowości projektu - innymi możliwościami dysponuje Rada Ministrów wyposażona w zespół ekspertów, innymi zaś grupa obywateli.

Kolejnym cennym aspektem pozwalającym na pozytywną ocenę recenzowanej monografii wśród innych publikacji poruszających zagadnienia $\mathrm{z}$ zakresu problematyki realizacji prawa inicjatywy ustawodawczej stanowią liczne nawiązania do wpływu członkostwa RP w UE na proces ustawodawczy. Autorka analizuje bowiem zjawisko oddziaływania integracji europejskiej na proces stanowienia prawa, omawia „nowe obowiązki” Parlamentu RP związane z koniecznością implementacji prawa stanowionego przez instytucje $\mathrm{UE}^{2}$.

1 Szerzej na ten temat: A. Bień-Kacała, Z. Witkowski, „Mania ustawodawcza” - przewlekła choroba polskiego parlamentu i sposoby jej leczenia, [w:] Nauki penalne wobec szybkich przemian socjokulturowych. Księga Jubileuszowa Profesora Mariana Filara, T. II, red. A. Adamski, J. Bojarski, P. Chrzczonowicz, M. Leciak, Toruń 2012, s. 536 i n.

2 Szerzej na ten temat m.in.: A. Frankiewicz, Pozycja parlamentów narodowych $w$ Traktacie Lizbońskim a deficyt demokracji w Unii Europejskiej, [w:] Prawo i gospodarka po Traktacie Lizbońskim, red. E. Kozerska, P. Malinowski, T. Scheffler, Opole 2011, s. 124-150; M. Serowaniec, Europeizacja tradycyjnych funkcji polskiego parlamentu w świetle postanowień Traktatu z Lizbony oraz ustawy kooperacyjnej z 8 października 2010 roku, „Studia Iuridica Toruniensia” 2014, T. XIV, s. 342. 
W pracy odnajdujemy trafną diagnozę, że próbując wypracować całościowe pojęcie projektu ustawy, należy zaznaczyć, że konstytucja ustanawia specjalną procedurę dla projektu ustawy, która ze względu na swój wyjątkowy charakter musi zostać rozpatrzona szybko - klauzula pilności. Analizowany jest także w pracy problem postępowania z projektem ustawy budżetowej oraz z projektem ustawy o zmianie konstytucji.

W rozdziale III zatytułowanym Podmioty prawa inicjatywy ustawodawczej odnajdujemy względnie szeroką analizę realizacji prawa inicjatywy ustawodawczej z perspektywy podmiotów, które zostały w nią konstytucyjnie uposażone. Za szczególnie istotne uważam rozważania dotyczące tzw. „prezydenckiej inicjatywy ustawodawczej”. Konstytucja rozróżnia dwa rodzaje prezydenckich inicjatyw ustawodawczych: pierwsza to inicjatywa zwykła z art. 118, druga to inicjatywa dotycząca zmiany konstytucji z art. 235. W pracy słusznie zauważa się, że powierzenie prezydentowi tak istotnej kompetencji - nieograniczonej żadnymi zastrzeżeniami, niepodlegającej kontrasygnacie - jest osobliwym i niezwykłym uprawnieniem. Przyznanie prezydentowi prawa do występowania $\mathrm{z}$ inicjatywą ustawodawczą to rozwiązanie właściwie niewystępujące $\mathrm{w}$ konstytucjach państw Europy Zachodniej, zwykle niepraktykowane w państwach o ustroju parlamentarno-gabinetowym. Podkreślając wagę przyznanego głowie państwa uprawnienia, Autorka dostrzega zagrożenia z niego wynikające, m.in. możliwość występowania przez prezydenta z projektami ustaw mogącymi godzić w zakres działania i kompetencje Rady Ministrów. Powołując się na poglądy doktryny, w pracy wskazuje się na okoliczności, w jakich głowa państwa powinna korzystać z przyznanego jej uprawnienia.

W najobszerniejszym IV rozdziale pracy trafnie podjęta została analiza postępowania projektodawczego Rady Ministrów. Nieco zwiększona w stosunku do pozostałych części pracy objętość tego rozdziału uzasadniona została tym, że rząd w RP uznawany jest za głównego inicjatora procesu ustawodawczego, gdyż odpowiada za prowadzenie polityki w państwie. Ponadto Rada Ministrów, m.in. ze względu na funkcje, jakie przyznała jej Konstytucja RP, pełni rolę podmiotu, któremu można przypisać największą efektywność legislacyjną.

Autorka szczegółowo analizuje proces opracowywania projektu ustawy przez Radę Ministrów w świetle aktualnych uregulowań prawnych. Wskazuje różnice pomiędzy nowym Regulaminem prac Rady Ministrów a poprzednim stanem prawnym. Za szczególnie cenne uważam detaliczne przed- 
stawienie procesu przygotowywania projektu ustawy przez Rząd. Autorka analizuje proces opracowywania założeń projektu ustawy oraz tryb opracowywania projektu ustawy, przedstawia charakter dokumentów rządowych. Przybliża w ten sposób czytelnikowi istotny, lecz często pomijany w literaturze przedmiotu opis trybu notyfikacji projektu ustawy.

Tkaczyk szczegółowo analizuje tryb postępowania zarówno z projektami tzw. ustaw zwykłych, projektem ustawy budżetowej, jak i z projektami ustaw wykonujących prawo Unii Europejskiej. Następnie opisuje rolę i działalność Rady Legislacyjnej - organu opiniodawczego i doradczego Rady Ministrów oraz Rządowego Centrum Legislacji.

W kolejności omawia postępowanie w sprawie inicjatywy ustawodawczej Senatu. Rozważania merytoryczne otwiera analiza postanowień Regulaminu Senatu dotyczących badanej w monografii problematyki.

Podobnie jak we wcześniejszych częściach pracy, Autorka starannie przybliża czytelnikowi przebieg procesu legislacyjnego w drugiej izbie parlamentu, uznawanej w tradycjach konstytucyjnych państw europejskich za „izbę rozwagi i refleksji”. Analizuje przebieg debaty plenarnej oraz proces głosowania nad uchwałą Senatu w sprawie wniesienia inicjatywy ustawodawczej. Jest to zagadnienie bardzo dobrze opisane w polskiej literaturze prawno-konstytucyjnej, ale zaletą tej pracy jest zgrabne usystematyzowanie problemu.

Następnie odnajdujemy w pracy krótki opis czynności poprzedzających wystąpienie z poselską inicjatywą ustawodawczą. Poza tym Autorka analizuje dwie kategorie poselskich projektów ustaw, mianowicie projekty ustaw pochodzące od komisji sejmowych oraz projekty ustaw wnoszone przez co najmniej 15 posłów. Zwięzłość analiz zawartych w rozdziale VI uzasadnia stwierdzeniem, iż w żadnym obowiązującym akcie prawnym nie przewidziano trybu przygotowywania projektu ustawy przez posłów lub komisje sejmowe, co sprawia, że nie ma wystarczających podstaw do przeprowadzania głębszych analiz tego akurat zagadnienia. Trudno zgodzić się z takim uzasadnieniem zaniechania analizy, zwłaszcza że poselskie inicjatywy stanowią de facto bardzo znaczący odsetek inicjatyw ustawodawczych w ogóle.

Autorka omawia też, zasygnalizowaną już we wcześniejszych częściach monografii, problematykę związaną z prezydencką inicjatywą ustawodawczą. Analizuje ona uregulowania konstytucyjne dotyczące tego szczególnego, niepodlegającego kontrasygnacie uprawnienia głowy państwa. Za interesu- 
jące uważam rozważania odnoszące się do legitymacji prezydenta do występowania z projektami ustaw dotyczącymi stanów nadzwyczajnych. Edyta Tkaczyk przedstawia przy tym także informacje o aktywności prezydentów $\mathrm{RP}$ w zakresie korzystania $\mathrm{z}$ prawa występowania $\mathrm{z}$ inicjatywą ustawodawczą, co może być przydatne dydaktycznie.

Następna część monografii poświęcona została trybowi postępowania w sprawie wykonania inicjatywy ustawodawczej przez obywateli. Autorka szczegółowo rekonstruuje wymogi, które spełnić powinny osoby chcące utworzyć Komitet Inicjatywy Ustawodawczej, a następnie przedstawia proces jego prac.

W końcowych rozdziałach E. Tkaczyk przybliża czytelnikowi problematykę związaną z warunkami prawnymi wniesienia projektu ustawy, a w konsekwencji omawia skutki, jakie wiążą się z dokonaniem tej czynności. Rozważania kończy analiza zasady dyskontynuacji prac legislacyjnych.

Dyskusja, do której skłania lektura monografii, potwierdza wyrażoną wcześniej opinię, że Autorka podjęła temat ważny i rozległy. Edyta Tkaczyk przedstawiła bowiem nie tylko „suchą analizę" praktykowanych rozwiązań prawnych, ale podjęła próbę udzielenia odpowiedzi na istotne i cały czas aktualne pytania, dotyczące m.in. możliwości opracowania dobrego projektu ustawy w aktualnych realiach prawnych oraz zasadności stworzenia jednego aktu, który kompleksowo regulowałby proces tworzenia prawa.

Książka adresowana jest do szerokiego kręgu odbiorców - badaczy prawa konstytucyjnego, studentów oraz wszystkich osób zainteresowanych problematyką tworzenia prawa. Przystępny, lecz jednocześnie niepozbawiony fachowych zwrotów język sprawia, że lektura monografii może być źródłem cennych wiadomości zarówno dla osób studiujących kierunki prawnicze, jak i podmiotów zajmujących się tworzeniem czy też badaniem prawa. Jak już zostało zaznaczone na początku, niezwykle cennym jest praktyczny wymiar rozważań Autorki. W związku z powyższym monografia Realizacja prawa inicjatywy ustawodawczej w polskim prawie konstytucyjnym może pełnić także rolę poradnika dla obywateli pragnących utworzyć Komitet Inicjatywy Ustawodawczej.

Dorota Kaniewska Uniwersytet Mikołaja Kopernika w Toruniu 